\title{
EFFICIENCY OF INFORMATION TECHNOLOGY IN CROATIAN TOURISM
}

\section{Maja Buljat}

Veleučilište Baltazar Zaprešić, Zaprešić, Hrvatska

\section{Suzana Đorđević}

Veleučilište Baltazar Zaprešić, Zaprešić, Hrvatska

\section{Barbara Franić}

Veleučilište Baltazar Zaprešić, Zaprešić, Hrvatska

CMESTE

JEL Category: E01, O50, Z31, Z32

\section{Apstrakt}

Svakodnevno se pronalaze nova sredstva i načini koji omogućuju sve veću efikasnost u poslovanju, odnosno dovode do veće profitabilnosti poslovanja poduzetnika u turizmu. Dinamično i neizvjesno okruženje mijenja poslovanje turističkih agencija nalažući im prilagodbu, prihvaćanjem novih izazova $i$ mogućnosti iz okoline. Turizam u Hrvatskoj ima izrazito visok udio u nacionalnom proizvodu, te je od velike važnosti za Hrvatsko gospodarstvo. Potrebno je neprekidno praćenje i evaluacija postojeće turističke ponude. Ulaskom na globalno tržište, poduzetnik ima priliku vrlo jednostavno i brzo upoznati kvalitetu, cijene usluga i asortiman ponude konkurencije što mu otvara mogućnosti i daje smjernice za organizaciju i usavršavanje vlastite ponude. S druge strane, sa strane potražnje, navike, želje i potrebe se sve više mijenjaju. Turist želi biti u kontaktu s cijelim svijetom, prikupljati informacije o turističkim destinacijama i njihovoj ponudi pristupiti brzo. Gotovo pola rezervacija u Hrvatskoj ostvari se virtualnim putem, a Internet $i$ društvene mreže potisnuli su tradicionalne izvore ponuda turističkih destinacija. Novi mediji uz pomoć novih informacijskih tehnologija omogućili su da se slike, tekst, zvukovi, video i drugi sadržaji prenose velikim brzinama na velike udaljenosti te tako doprinose ukupnim promocijskim aktivnostima u turizmu te pozitivan utjecaj na razvoj hrvatskog turizma, kao i cjelokupnog gospodarstva.

Ključne riječi: Internet, devizni priljev, turizam, BDP, zaposlenost, organizacija poslovanja.

\section{Adresa autora zaduženog za korespodenciju: Barbara Franić \\ 麦=" barbara.franic@gmail.com}

\section{Abstract}

Each day there are new tools and methods that enable business performance to be more efficient, and lead to higher business profitability in the 
tourism industry. Because of the dynamic and uncertain environment, management of travel agencies has changed, forcing them to adapt, accept new challenges and find new opportunities. Tourism in Croatia makes an extremely large part of the national product, and it is of major importance for Croatian economy. It is necessary to continuously monitor and evaluate the existing tourist offer. By entering the global market, entrepreneurs have an opportunity to easily and quickly get acquainted with the quality, price and competitor's' offer, which opens the possibilities and provides guidance for organizing and perfecting their own offers. On the other hand, from the demand side, habits, needs and wishes are increasingly changing. Tourists want to be in touch with the whole world, to find out information about tourist destinations and access the offers quickly. Almost half of reservations in Croatia is done virtually, and the Internet together with social networks has pushed back the traditional means of finding travel offers. New Media, with the assistance of new information technologies, has made it possible for images, text, sounds, videos and other contents to be transferred at high speed across vast distances, and thus contributing to the overall promotion of tourism activities and producing a positive impact on the development of Croatian tourism and overall economy.

Keywords: Internet, foreign exchange earnings, tourism, GDP, employment, business organization

\section{UVOD}

Važnost turizma proizlazi iz brojnih ekonomskih učinaka, kao što su: rast zaposlenosti, rast dohotka, rast javnih prihoda te rast kapitalnih ulaganja. Razvoj turizma donosi brojne ekonomske koristi privatnom, javnom i neprofitnom sektoru te lokalnom stanovništvu. Nedostatak odgovarajućeg ekonomskog mjerenja učinaka ostvarenih kroz turizam često vodi i podcjenjivanju koristi od turizma, posebice $u$ usporedbi s ostalim gospodarskim sektorima. Turizam u Hrvatskoj u velikoj je mjeri izvozno orijentiran, što ste manifestira povećanim udjelom noćenja stranih turista u ukupnim noćenjima. U Hrvatskoj je 2014. prema podacima Ministarstva turizma boravilo 13,1 milijun turista što predstavlja rast za 5,6\% u odnosu na 2013. U ukupnom broju dolazaka dominiraju strani turisti s 11,6 milijuna (rast od 6,2\%), dok broj dolazaka domaćih turista iznosi 1,5 milijuna (rast od 1,4\%). Primjetan je konstantan rast udjela turističke djelatnosti $u$ bruto domaćem proizvodu. Povećanje udjela prihoda ostvarenih od turizma u ukupnom BDP-u Hrvatske ukazuje na to kako je turistički sektor od velike važnosti kada je u pitanju pozitivan ekonomski rast Hrvatske. Recesija koja u Hrvatskoj traje od 2008. godine utjecala je gotovo na sve sektore gospodarstva, u najmanjoj mjeri na turizam. Devizni prihodi nakon velikog pada $u$ 2009. godini bilježe konstantan rast, zaposlenost u turističkom sektoru također bilježi porast. Navedeni podaci ukazuju na važnost ulaganja u turistički sektor te važnost prilagodbe i organizacije poslovanja novim trendovima koji su u najvećoj mjeri orijentirani tehnološkom razvoju.
Mediji i tehnologija smanjili su svijet, te će se ljudske potrebe izjednačiti stvarajući jedinstveno globalno tržište koje će dominirati uz svjetski najuspješnije tržišne marke. Tehnologija okreće svijet prema "jedinstvenim ujedinjenim zajednicama", i nije više bitno kojoj rasi, religiji ili kulturi pripadaju - oni svi skupa ubiru plodove tehnologije u bilo kojem obliku (Koncul, 2004). Novi potrošački trendovi, političke promjene, nova tehnologija, fragmentacija tržišta, globalizacija, vertikalna, horizontalna i dijagonalna integracija, zabrinutost zbog okoliša, gospodarska integracija i mnoga druga važna događanja - sve to pridonosi složenosti upravljanja poduzećem u turizmu. Razvoj gospodarstva biti će nezamisliv bez Interneta, prvenstveno zbog dominiranja stranih turista. Cilj ovog rada je prikazati važnost informacijske tehnologije u turizmu, odnosno Interneta kao portala za prikupljanje informacija o turističkoj ponudi i prednosti korištenja online rezervacijskog sustava koji se ujedno nameće kao osnovni resurs menadžmenta tvrtke.

\section{UTJECAJ TURIZMA NA GOSPODARSTVO HRVATSKE}

Turističko gospodarska djelatnost je jedna od važnih gospodarskih djelatnosti u Hrvatskoj. Bez sumnje je značajan izvozni proizvod i generator zapošljavanja. Njezin uspješan razvoj je osnovica za razvitak i drugih gospodarskih djelatnosti u Hrvatskoj, te njezino uključivanje u europske i svjetske turističke tijekove. Usprkos oscilacijama u svjetskoj ekonomiji i raznim događajima koji narušavaju globalnu stabilnost, turizam pokazuje 
otpornost na promjene u ekonomskom društvenom okruženju.

Turizam je iznimno složen gospodarski sustav sastavljen od niza fragmenata strukturno različitih gospodarskih grana i djelatnosti u svim sektorima nacionalnog gospodarstva. Turizam se definira kao visoko sofisticiran integralni sustav u okviru nacionalnog gospodarstva čiji djelokrug i struktura nadilazi ekonomske kategorije djelatnosti, grane, industrije i sektora, a čine ga međusobno povezani, heterogeni, međuovisni i komplementarni fragmenti različitih gospodarskih grana i djelatnosti koji zajedno čine logičku, funkcionalnu i uravnoteženu cjelinu. To je skup komplementarnih proizvoda i usluga različitih gospodarskih grana i djelatnosti, bez obzira što u jednom njegovom segmentu proizvodi ili usluge međusobno konkuriraju, proizvodi i usluge u turizmu su u velikoj većini međusobno komplementarni, a ne konkurentni (Šuštar, 2013).

Tablica 1. Ostvareni prihodi od turizma u razdoblju od 2009. - 2014. godine

\begin{tabular}{|c|c|c|c|c|}
\hline Godina & $\begin{array}{c}\text { Prihodi od turizma } \\
\text { (u mlrd. eura) }\end{array}$ & $\begin{array}{c}\text { Verižni } \\
\text { indeks }\end{array}$ & $\begin{array}{c}\text { Stopa } \\
\text { promjene }\end{array}$ & $\begin{array}{c}\text { Bazni } \\
\text { indeks }\end{array}$ \\
\hline $\mathbf{2 0 0 9 .}$ & 6,4 & - & - & 100 \\
\hline $\mathbf{2 0 1 0 .}$ & 6,2 & 96,9 & $-\mathbf{3 , 1}$ & 96,9 \\
\hline $\mathbf{2 0 1 1 .}$ & 6,6 & 106,5 & $+6,5$ & 103 \\
\hline $\mathbf{2 0 1 2}$. & 6,8 & 103 & +3 & 106 \\
\hline $\mathbf{2 0 1 3 .}$ & 7,2 & 105,9 & $+\mathbf{5 , 9}$ & 112,5 \\
\hline $\mathbf{2 0 1 4 .}$ & 7,4 & 102,8 & $+\mathbf{2 , 8}$ & 115,6 \\
\hline
\end{tabular}

Izvor: Vlastita izrada autora prema ( Sektorska analiza, Ekonomski Institut Zagreb 2015)

Stanje na financijskim tržištima i globalnoj ekonomiji 2009. godine imalo je negativan utjecaj i na sektor turizma. Devizni prihodi od turizma koji su svoj vrhunac ostvarili 2008. godine, prve dvije godine krize bili su u padu, usprkos tome, brzo su se počeli oporavljati, te su dvije godine nakon toga zabilježili rast, što je prikazano verižnim i baznim indeksima u tablici 1. Tendencija rasta primjetna je od 2011. godine kada su se ukupni devizni prihodi povećali za 6,5 posto u odnosu na isto razdoblje 2010. godine.

U Hrvatskoj je 2014. (Ministarstva turizma, 2014) boravilo 13,1 milijun turista što predstavlja rast za $5,6 \%$ u odnosu na 2013. U ukupnom broju dolazaka dominiraju strani turisti s 11,6 milijuna (rast od 6,2\%), dok broj dolazaka domaćih turista iznosi 1,5 milijuna (rast od 1,4\%). Broj noćenja turista porastao je za $2,6 \%$ te je ukupno iznosio 66,5 milijuna od čega se na noćenje stranih turista odnosi 61,3 milijuna, a na domaća noćenja 5,2 milijuna. Prosječan broj dana boravka turista iznosio je 5 dana. Gledano prema načinu dolaska broj individualnih turista iznosio je 8,2 milijuna (6,2\% više nego godinu prije), a ostvarili su 43,7 milijuna noćenja što predstavlja rast od $4 \%$ u odnosu na godinu prije, dok je organiziranih turista bilo 4,9 milijuna (4,6 \% više nego 2013. godine), a ostvarili su 22,8 tisuća noćenja na istoj razini kao i 2013. godine. Iz navedenih podataka vidljivo je da broj organiziranih dolazaka ima veći rast $u$ odnosu na individualne. To je posljedica sve većeg dolaska stranih turista iz udaljenih destinacija, na prvom mjestu po broju dolazaka je Njemačka, druga Slovenija i treća Italija. U 2014. godini od turizma, odnosno putovanja, u Hrvatskoj je ostvareno 7,4 milijardi eura prihoda, što predstavlja godišnji rast od 2,8 posto. Godinu prije udio prihoda od putovanja u BDP-u iznosio 17,2 posto, što je 0,6 posto više. Nakon rasta prihoda od turizma u prvih devet mjeseci 2014. godine, pozitivan trend nastavljen je i $u$ četvrtom tromjesečju, u kojem je ostvareno 622,8 milijuna eura prihoda od turizma ili 4,4 posto više nego $u$ istom razdoblju 2013. godine. Također, u četvrtom tromjesečju udio prihoda u BDP-u iznosio je 5,8 posto, što je 0,2 posto više od udjela ostvarenog $u$ istom razdoblju 2013. godine. Sektor turizma je i u 2014. (UNWTO, 2014), na globalnoj razini zabilježio iznadprosječne stope rasta. Udio koji zaposleni u turističkom sektoru imaju u ukupnom broju zaposlenih u Republici Hrvatskoj raste već petu godinu zaredom. Dok je 2009. godine 5,9 posto zaposlenih u Republici Hrvatskoj bilo zaposleno u turističkom sektoru, u 2014. godini taj se postotak popeo na gotovo 8 posto. Rastući udio 
turističkog sektora u ukupnom broju zaposlenih djelomično je posljedica pada ukupnog broja zaposlenih u Republici Hrvatskoj uslijed dugotrajne krize.

\section{MENADŽMENT I VAŽNOST INFORMACIJSKIH TEHNOLOGIJA U POSLOVANJU}

Stalne promjene u okruženju poduzeća, među kojima se danas često navode: kompleksnost okruženja, heterogenost, dinamičnost i neizvjesnost, potiču menadžment na stalnu aktivnost, što podrazumijeva konstantno praćenje i predviđanje budućih poslovnih promjena, kako bi se mogle donositi kvalitetne odluke koje poduzeću moraju osigurati trajno i uspješno poslovanje. Da bi se donijele kvalitetne odluke potrebno je poznavati različite vrste informacija, odnosno potrebne su potpune i kvalitetne informacije koje su ujedno i dostupne na vrijeme. Za kvalitetno prikupljanje i pohranjivanje informacija te njihovo učinkovito pretraživanje i upotreba koja omogućuje donošenje kvalitetnih odluka, nužna je i informacijska tehnologija. Imajući na umu globalne trendove koji se odvijaju na turističkom tržištu, čiji se utjecaj reflektira na postojećim turističkim prostorima stvarajući pritom i nove, u ovom radu ukazat će se na važnost Interneta, koja u potpunosti utječe na transformaciju procesa poslovanja ili djelomično na promjenu organizacije poslovanja turističkih agencija.

Menadžer kao poduzetnik mora stalno propitivati nove mogućnosti organizacije poslovanja svojeg poduzeća kako bi se usmjerio na razvoj novih proizvoda ili usluga, ili svoje poslovanje proširio na novo tržište. Menadžer u tom slučaju potiče i vodi promjene u poduzeću. Stoga je potrebna stalna komunikacija na razini top menadžmenta i menadžmenta informacijskih sustava, kako bi se u tvrtci upravljalo informacijskom tehnologijom na zadovoljavajući način. Isto tako i sami korisnici moraju biti uključeni u cjelokupan proces kroz komunikaciju svojih potreba i mogućnosti unapređenja poslovnih procesa korištenjem IT mogućnosti. Funkcija upravljanja informacijskim sustavima predstavlja potpornu djelatnost svim poslovnim funkcijama i poslovnim procesima i predstavlja mogućnost unapređenja njihova funkcioniranja. Sukladno s tipičnim poslovnim funkcijama (strateško planiranje, razvijanje proizvoda i marketing, proizvodnja, operacije i distribucija, usluga kupcima) mogu se identificirati IT funkcije koje podupiru njihovo funkcioniranje (potpora strateškom planiranju, razvijanje aplikacija - planiranje, dizajn i proizvodnja, potpora operacijama, help desk) (Miller, 2001).

Ulaganje $u$ informacijsku tehnologiju predstavlja sve veći dio investicija u poslovanju tvrtki. Stoga slobodno možemo reći da iznos ulaganja u IT iznosi više od polovine investicijskih budžeta većine uslužnih tvrtki u razvijenim zemljama, budući da su njihovi glavni "proizvodi" informacije i usluge. Nerijetko se postavlja se pitanje koliko su zapravo ulaganja u IT opravdana obzirom da uzimaju sve veći postotak ukupnih ulaganja određene tvrtke. No, odgovor se nameće sam po sebi budući da je evidentno da upotrebom suvremene IT tvrtke mogu steći određene konkurentne prednosti kojima mogu potpuno potisnuti i marginalizirati konkurenciju na tržištu. Zbog toga se nameće potreba kvalitetnog upravljanja informacijskom tehnologijom $u$ suvremenim tvrtkama i njegove organizacije na način da iznosi najveću moguću vrijednost za poslovanje (Miller, 2001).

Internet u turizmu predstavlja temeljnu stratešku odrednicu poslovanja poduzeće iz sektora turizma. Internetske stranice predstavljaju informacije o određenoj lokaciji, turističkom objektu, smještaju, pogodnostima, cijenama, aktivnostima i dodatnim uslugama. U svijetu Interneta portal znači web stranicu koja jest ili želi biti na ulaznim vratima $u$ Internet, tj. glavna polazišna točka. Portal skuplja različite sadržaje i nudi in web korisnicima sa svim uslugama koje mogu poželjeti na jednom mjestu (Kalakota,2002). Cilj svakog poslovnog sektora u turizmu mora biti da dobije pravog turista u pravo vrijeme. Naravno $\mathrm{s}$ najboljom ponudom za njega i da smo mu dostupni od 0-24. To nam jedino omogućuje poslovanje u digitalnom okruženju. Sva komunikacija, trgovina te rezervacija smještaja i pružanje drugih informacija vezanih uz turističku ponudu svodi se na jedan interaktivni kanal, a to je Internet. Web tehnologije omogućavaju svima, čak i onim malima, da budu prisutni na online tržištu. No, poznavati samo tehnologije nije dovoljno, već je potrebno imati i jasnu prodajnu strategiju za online kupce - goste u turizmu. Najisplativiji i najsigurniji način da se turističkom ponudom istakne među konkurencijom i uspješno osvoji Internet tržište je ulaganje u vlastitu web 
stranicu. Smanjit će se troškovi poslovanja, jer je Internet promocija najjeftiniji način reklamiranja turističkih ponuda i aranžmana. Da bi se postigli uspješni i učinkoviti rezultati u Internet oglašavanju nije dovoljno samo osigurati sredstva nego treba učiniti niz koraka koji će dovesti do stvaranja originalne i prepoznatljive ponude. Da bi Internet oglašavanje bilo djelotvorno treba stvoriti atraktivne oglase i web stranice koje će imati mogućnost stalne nadogradnje i poboljšanja, koje će uvijek svojom originalnošću i kreativnošću ići ispred konkurencije, te koje će posjetitelje Internet oglasa učinkovito pretvarati u hrvatske turističke goste.

Planirana sredstva za upravljanje internetskim stranicama Hrvatske turističke zajednice tijekom 2015. iznosila su 3.000 .000 kuna koja su se većim dijelom usmjerila u redizajn službene internetske stranice te nabavu novih tekstualnih, video i drugih multimedijskih sadržaja. Od ukupnih 3.000 .000 $\mathrm{kn}$, planirana sredstva za upravljanje Internet stranicom iznosila su $2.500 .000 \mathrm{kn} \mathrm{i} 700.000 \mathrm{kn}$ na Web nautiku.

Tablica 2. Planirana sredstva za Online oglašavanje u 2015. godini

\begin{tabular}{|l|c|}
\hline & Planirana sredstva \\
\hline 1. $\quad$ Komunikacija na društvenim mrežama & $\mathbf{5 . 0 0 0 . 0 0 0}$ \\
\hline 1.1. Oglašavanje na društvenim mrežama & 4.200 .000 \\
\hline 1.1.1. Oglašavanje na Facebooku & 2.200 .000 \\
\hline 1.1.2. Oglašavanje na YouTube kanalu & 2.000 .000 \\
\hline 1.2. Produkcija sadržaja za objavu na društvenim mrežama & 500.000 \\
\hline 1.3. Nagradne igre na društvenim mrežama & 300.000 \\
\hline 2. Mobilni marketing & $\mathbf{1 . 0 0 0 . 0 0 0}$ \\
\hline 2.1. Oglašavanje & 600.000 \\
\hline 2.2. Produkcija sadržaja za mobilni marketing & 400.000 \\
\hline
\end{tabular}

Izvor: Vlastita izrada autora prema (Hrvatska turistička zajednica, Godišnji program rada i financijski plan za 2015.)

Izvor financiranja planiranih novčanih sredstava je najvećim dijelom iz državnog proračuna, dok je manji dio financiran iz boravišnih pristojbi i turističkih članarina. Svakodnevna prisutnost i komunikacija na jeziku korisnika od velike je važnosti za jačanje brenda, dodatno povezivanje, stvara temelje za odnose s potencijalnim gostima, pojačava njihovu vjernost, mogu se prepoznati problemi u samom nastanku, a zauzvrat sam gost promovira proizvod ili uslugu internetskoj zajednici. lako po kanalima komunikacije glas jednog brenda može varirati, njegove vrijednosti moraju biti konzistentne u svakoj interakciji $s$ korisnicima. $\mathrm{Na}$ temelju navedenog vidi se da je Hrvatska turistička zajednica prepoznala važnost korištenja Interneta u turizmu, odnosno da mogućnost oglašavanja i prodaje turističkih aranžmana korištenjem online kanala dovodi do povećanja konkurentnosti turističkog tržišta. Ulaganja novčanih sredstava iz godinu u godinu je sve veća, ali i učinkovita.
Online putničko tržište u velikoj mjeri je napredovalo te postaje sve značajnije u pogledu turista. Ne samo na strani turističke ponude nego i na strani turističke potražnje. Osim već navedenih prednosti, također veliku prednost ovakvom obliku trgovanja ističe se i u mogućnosti plaćanja: kreditnom karticom, pouzećem u domaćem prometu, bezgotovinskom uplatom te slanjem obavijesti o plaćanju putem e-maila ili elektroničkim plaćanjem (elektroničkim transferom sredstava na elektronički račun prodavača). Najočitiji tehnološki izazov u turizmu je brzo širenje informacija i općenito komunikacija putem Interneta. Te aktivnosti se odvijaju na strani potražnje, u obliku B2C (business to customer) online trgovine, ali i na strani ponude u obliku B2B (business to business) online trgovine tj. komunikacije. Ova teza počiva na međusobnoj sinergiji turizma i Interneta. Svjetski i europski turizam doživljava značajne promjene posljednjih godina, te se nalazi pod rastućim utjecajem globalnih mega trendova, a Internet je jedan od njih (Andrlić, 2007). Internet je u sektoru turističke 
industrije, kao i u svim drugim vrstama poslovanja, te se koristi kao komunikacijski, transakcijski i promijenio klasične metode i koncepte poslovanja, distribucijski kanal.

- Online tržište putovanja (mlrd \$) $\quad$ Rast tržišta (\%)

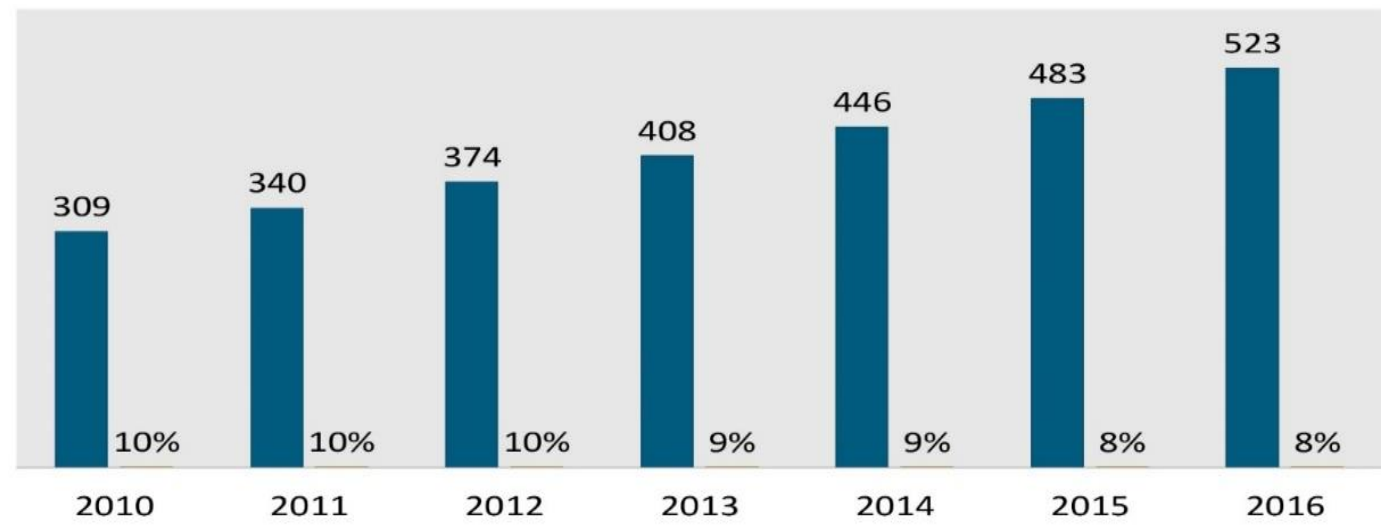

Slika 1. Online putničko tržište (svijet)

Izvor: (Ružić, Biloš, \& Kelić, 2014)

\section{ANALIZA INTERNETA KANALA U KAO VAŽNOG ORGANIZIRANJU PUTOVANJA}

Osnovni cilj istraživanja jest utvrditi važnost Interneta u organiziranju i rezerviranju putovanja. Za istraživanje je korišten anketni upitnik s 13 pitanja i proveden je između 21. i 29. siječnja 2016. godine. Osnovni skup čine studenti Veleučilišta Baltazar Zaprešić u dobi od 19 do 49 godina. Uzorak obuhvaća 84 ispitanika od čega je $31 \%$ muškog spola, a $69 \%$ ženskog spola. Anketni upitnik slao se online, nakon dovršetka istraživanja dobiveni odgovori koordinirani su i analizirani u Microsoft Excelu i statističkim formulama. Većina ispitanika - 97,6\% posjeduje računalo, dok samo $2,4 \%$ ispitanika ne posjeduje računalo, no bez obzira na taj mali udio, svi ispitanici koriste Internet. Od ukupnih 100\% ispitanika, 20\% provodi minimalno 15 min do 1 sat na dan koristeći Internet, $36 \%$ provodi 1 do 2 sata, $15 \%$ od 2 do 3 sata, a $29 \%$ ispitanika u ukupnom broju provodi više od 3 sata na dan koristeći Internet. Zanimljivo je da nema velike razlike $u$ vremenu korištenja interneta. Svi ispitanici barem jedanput godišnje svoje vrijeme provedu na putovanju (32,1\%), 2 puta godišnje na putovanje ode $27,4 \%$ ispitanika, 3 puta godišnje $13,1 \%$ dok neki ispitanici mogu si priuštiti putovanje više od 3 puta godišnje $(27,4 \%)$. S obzirom na učestalost putovanja postavlja se pitanje kako najlakše rezervirati i organizirati putovanje?
Tablica 3. Način prikupljanja informacija o destinaciji

\begin{tabular}{|l|r|}
\hline \multicolumn{1}{|c|}{$\begin{array}{c}\text { Prikupljanje informacija o } \\
\text { destinaciji }\end{array}$} & Udio \% \\
\hline Već sam znao/la za destinaciju & $15,5 \%$ \\
\hline Putem Interneta & $70,2 \%$ \\
\hline Preko prijatelja i rodbine & $9,5 \%$ \\
\hline Preko TV & $0 \%$ \\
\hline Preko turističkih agencija & $3,6 \%$ \\
\hline Ostalo & $1,2 \%$ \\
\hline
\end{tabular}

Izvor: Vlastita izrada autora

Iz tablice je vidljivo da je više od polovica ispitanika $(70,2 \%)$ odgovorila da informacije o destinaciji prikuplja putem Interneta, $15,5 \%$ ispitanika već su boravili u istoj turističkoj destinaciji i svidjelo im se te zbog povoljne ponude (blizina turističke destinacije, povoljne cijene), već znali o istoj. Samo $9,5 \%$ ispitanika informacije je dobilo na temelju preporuke rodbine i prijatelja, što ukazuje na to da na strani turističke potražnje postoje sve različitije želje i potrebe turista, te zbog toga ponuda mora biti široka i raznovrsna, konzistentna. Sve manje se traže informacije putem turističkih agencija, što se može vidjeti po rezultatima prikazanih u tablici. Kada je riječ o načinu rezerviranja putovanja $76,2 \%$ ispitanika rezervira svoj putovanje putem Interneta, dok $23,8 \%$ preko turističkih agencija. 


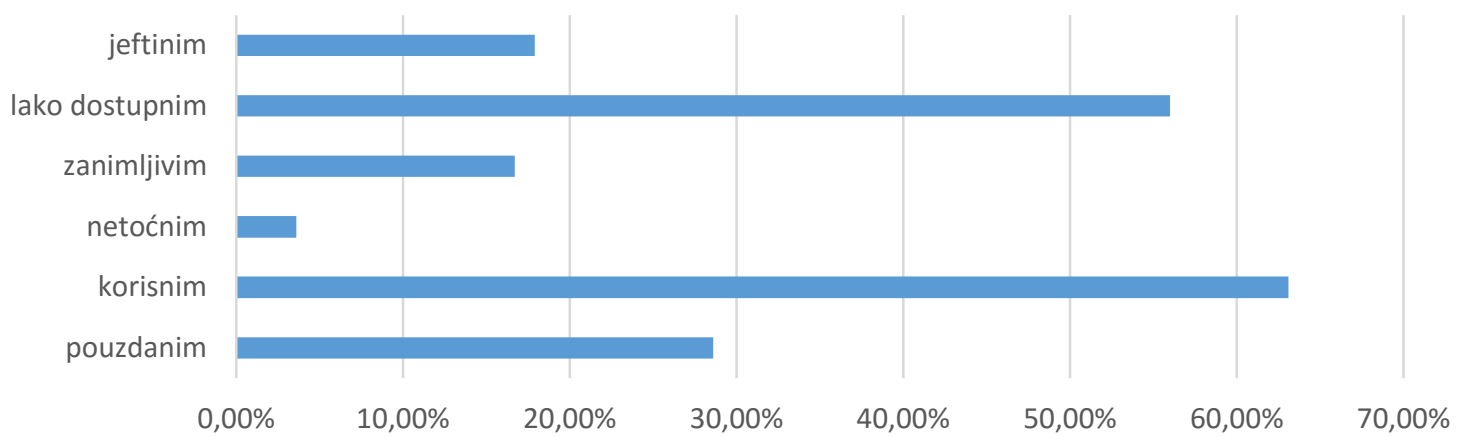

Grafikon 1. Informacije dobivene putem Interneta

Istraživanje pokazuje da ispitanici smatraju informacije dobivene putem Interneta prvenstveno korisnim $(63,1 \%)$, lako dostupnim (56\%), zatim pouzdanim, zanimljivim, jeftinim, a mali udio ispitanih smatra netočnim. Na Internetu je mnogo jeftinije, brže i općenito jednostavnije $s$ jedne strane prezentirati svoju ponuda, a s druge strane, sa strane potražnje na temelju navedenog i doći do informacija. Ispitanici smatraju Internet kao izvor informacija odličnim $(60,7 \%)$, dobrim smatra $38,1 \%$ dok manji udio ispitanika $1,2 \%$ smatra Internet kao loš izvor informacija. lako je Internet vrlo važan izvor informacija ispitanicima koji su sudjelovali u istraživanju, više od polovine $(57,1 \%)$ povremeno provjeri kvalitetu informacija, 22,6\% uvijek provjerava kvalitetu, a samo $20.2 \%$ vjeruje informacijama dobivenih putem Interneta i nikad ne provjerava njihovu kvalitetu. Bez obzira na kvalitetu informacija, smatraju plaćanje putem Interneta sigurnim $78,6 \%$ u ukupnom udjelu.

\section{ZAKLJUČAK}

Hrvatski turistički sektor pratio je globalne trendove porasta fizičkih i financijskih pokazatelja te se pokazao kao sektor gospodarstva koji je prvi pronašao put iz gospodarske krize. Potrebno je neprekidno praćenje i evaluacija postojeće turističke ponude. Ulaskom na globalno tržište, poduzetnik ima priliku vrlo jednostavno i brzo upoznati kvalitetu, cijene usluga $\mathrm{i}$ asortiman ponude konkurencije što mu otvara mogućnosti i daje smjernice za usavršavanje vlastite ponude. $S$ druge strane, sa strane potražnje, navike, želje i potrebe se sve više mijenjaju. Turist želi biti u kontaktu s cijelim svijetom, prikupljati informacije o turističkim destinacijama i njihovoj ponudi pristupiti brzo. Gotovo pola rezervacija u Hrvatskoj ostvari se virtualnim putem, a Internet i društvene mreže potisnuli su tradicionalne izvore turističkih destinacija. Promjenjivi gospodarski uvjeti, promjene u ponašanju potrošača i razvoj novih tehnologija uzrokovat će nastanak novih tržišta. Jedan od najvažniji trendova koji će imati utjecaj na potrošače je tehnološko ubrzanje. Zbog sve većih iznosa ulaganja u informacijsku tehnologiju, sve važnijima postaju načini na koje tvrtke ulažu i koriste se IT-om. Može se reći da sposobnost uspješnog upravljanja informacijskom tehnologijom polako prerasta u jednu od

glavnih strateških prednosti brojnih tvrtki. Sa sve većom raširenošću i primjenom Interneta $u$ gospodarski razvijenim zemljama, sve značajniji postaje trend elektroničkog poslovanja, tj. usmjerenje svih resursa tvrtke na formiranje adekvatnog poslovnog modela koji omogućuje efikasno poslovanje posredstvom Interneta. Da bi se mogla pravilno pozicionirati na dinamičnom $i$ konkurentnom tržištu potrebno je da prati suvremene trendove kroz koje se identificiraju kretanja potražnje, nove tržišne prilike, područja mogućih ulaganja i infrastrukturne potrebe. Pojava Interneta donijela je i novu tržišnu kategoriju, elektronsko poslovanje. "Pod e poslovanjem podrazumijevam sve poslovne radnje kod kojih se izvedba ključnih operacija, upravljanja, financiranja, inovacija, proizvodnje, distribucije, prodaje, odnosa sa zaposlenicima te odnosa $s$ kupcima, odvija najvećim dijelom putem ili na Internetu ili drugim računalnim mrežama, bez obzira na vrstu veze između virtualnih i fizičkih dimenzija tvrtke. Koristeći Internet kao temeljno sredstvo komunikacije i obrade inovacija, poduzeće prisvaja mrežu kao svoj organizacijski oblik" (Castells, 2003). Prodaja, distribucija i 
promocija predstavljaju vrlo važne komponente u turizmu. Plasirati turističku ponudu na određenom turističkom tržištu manifestira se na dva najčešća oblika distribucije: izravnu distribuciju i neizravnu distribuciju. Proces prodaje i distribucije intenziviran je primjenom informatičke tehnologije. $\mathrm{Na}$ temelju provedenog istraživanja, ispitanici su se složili da je puno povoljnije, jednostavnije, jeftinije, zanimljivije pregledati ponudu koju nude ugostitelji diljem svijeta korištenjem Interneta, te iz svog doma napraviti plan svog putovanja, nego nazvati putničku agenciju, izraziti svoje želje, te nadati se da su odradili sve kako treba i po realnoj cijeni. Promatrane u kontekstu komunikacije i informiranja, informacijske tehnologije, u kojima se posebice ističe Internet, imaju snažan utjecaj na razvoj turizma. Informacijske tehnologije su približile potencijalnim turistima turistička odredišta, te olakšala promjenu mjesta prebivališta u svrhu ostvarenja turističke potrebe.

\section{CITIRANI RADOVI}

Andrlić, B. (2007). Primjena E-marketinga u turizmu. Poslovna izvrsnost, 1(2). 85-97

Castells, Manuel (2003). Internet galaksija: razmišljanje o internetu, poslovanju i društvu. Zagreb, Naklada Jesenski i Turk.

Hrvatska turistička zajednica (2015) Godišnji program rada i financijski plan za 2015. Preuzeto sa: http://business.croatia.hr/Documents/3503/Program-rada-2015.pdf (28.10.2015.)

Kalakota, R. (2002). E - poslovanje 2.0., Mate, Zagreb

Koncul, N. (2004). Položaj turizma u Globalnim Europskim Integracijskim Procesima, More i turizam, ISSN 0469-6255 (206-213), UDK 338.48:061.1 (4-67 EU). Preuzeto sa: file://C:/Users/Maja\%20Buljat/Downloads/7_koncul_niko.pdf (14.11.2015.)

Muller, J. (2001). Upravljanje informacijskom tehnologijom u suvremenim tvrtkama te Hrvatska poslovna praksa korištenja Informacijskih tehnologija, Preuzeto sa: http://hrcak.srce.hr/search/?q=upravljanje+informacijskom+tehnologijom (20.02.2016.)

Ministarstvo turizma (2014). Turizam u brojkama http://www.mint.hr/ (13.12.2015.)

Mirošević, H. (2015). Sektorska analiza turizma. Ekonomski Institut Zagreb. Preuzeto sa: http://www.eizg.hr/hr-HR/Sektorske-analize-993.aspx (3.3.2016.)

Ružić, D., Biloš, A., \& Kelić I. (2014). Rezervacijski sustavi na internetu, E-marketing. Ekonomski fakultet u Osijeku. Preuzeto sa: http://www.efos.unios.hr/e-marketing/wpcontent/uploads/sites/5/2013/04/e-marketing2013-11-rezervacijski-sustavi.pdf(28.10.2015.)

Šustar, K. (2013). Specifičnosti nacionalnog turizma, Lider, HUP Zagreb d.d. - UPUHH 2013.

World Tourism Organization (2015). UNWTO Annual Report 2014. Madrid: UNWTO. Preuzeto sa: http:// dtxtq4w60xqpw.cloudfront.net/sites/all/files/pdf/unwto_annual_report_2014.pdf (12. 2. 2016.).

Datum prve prijave:

Datum prijema korigovanog članka:

Datum prihvatanja članka:
14.03.2016.

02.04.2016.

23.06.2016.

\section{Kako citirati ovaj rad? / How to cite this article?}

Style - APA Sixth Edition:

Buljat, M., Đorđević, S., \& Franić, B. (2016, July 15). Efikasnost informacijskih tehnologija u turizmu Republike Hrvatske. (Z. Čekerevac, Ed.) FBIM Transactions, 4(2), 34-42. doi:10.12709/fbim.04.04.02.03 
Style - Chicago Sixteenth Edition:

Buljat, Maja, Suzana Đorđević, and Barbara Franić. 2016. "Efikasnost informacijskih tehnologija u turizmu Republike Hrvatske." Edited by Zoran Čekerevac. FBIM Transactions (MESTE) 4 (2): 34-42. doi:10.12709/fbim.04.04.02.03.

Style - GOST Name Sort:

Buljat Maja, Đorđević Suzana and Franić Barbara Efikasnost informacijskih tehnologija u turizmu Republike Hrvatske [Journal] // FBIM Transactions / ed. Čekerevac Zoran. - Belgrade : MESTE, July 15, 2016. - 2 : Vol. 4. - pp. 34-42.

Style - Harvard Anglia:

Buljat, M., Đorđević, S. \& Franić, B., 2016. Efikasnost informacijskih tehnologija u turizmu Republike Hrvatske. FBIM Transactions, 15 July, 4(2), pp. 34-42.

Style - ISO 690 Numerical Reference:

Efikasnost informacijskih tehnologija u turizmu Republike Hrvatske. Buljat, Maja, Đorđević, Suzana and Franić, Barbara. [ed.] Zoran Čekerevac. 2, Belgrade : MESTE, July 15, 2016, FBIM Transactions, Vol. 4, pp. 34-42. 